\title{
Identity politics and uses of the past with European national museums
}

\author{
Peter Aronsson*
}

\begin{abstract}
The article presents a research project on identity politics in Europe. European National Museums: Identity politics, the uses of the past and the European citizen (EuNaMus, www.eunamus.eu) explores the creation and power of the heritage created and presented by European national museums. National museums are defined and explored as processes of institutionalized negotiations where material collections and displays make claims and are recognized as articulating and representing national values and realities. Questions asked in the project are why, by whom, when, with what material, with what result and future possibilities are these museums shaped.
\end{abstract}

Key words: National museum, identity politics, uses of the past, Europe, comparative study.

The level of investments in national museums is high in contemporary society. The motives and hopes are often a mixture of a will to secure a scientific and relevant understanding of the national heritage, community integration, stimulating creativity and cultural dialogue and creating attractions for a bourgeoning experience economy. The Netherlands is planning for a new national museum for communicating a stronger ethnic canon, a path also chosen in Denmark. A great many other museums in Canada and New Zealand and also in Sweden hail a more multi-cultural approach, downplaying the traditional national aspect of narrative and inviting new citizens to a more diverse idea of society. Ethnographic museums open with a post-colonial invitation to dialogue all over the world in tension with strong demands for restituting objects ranging from the human remains of Samis, to the Elgin Marbles of Acropolis. It is a contested billiondollar cultural industry creating, negotiating and reinforcing ideas of values, belonging and ownership.

The European National Museums: Identity politics, the uses of the past and the European citizen (EuNaMus, www.eunamus.eu) research project explores the creation and power of the heritage created and presented by European national museums to the world, Europe and its states, as an unsurpassable institution in contemporary society. National museums are defined and explored as processes of institutionalized negotiations where material collections and displays make claims and are recognized as articulating and representing national values and realities. Questions asked in the project are why, by whom, when, with what 
118 material, with what result and future possibilities are these museums shaped.

\section{Negotiating MusEums}

Many of the negotiations and conflicts behind the scenes in museums have long-standing trajectories, not by being mishaps but as part of the value of the institutions in making them into relevant cultural forces which have been at play over the last two and a half centuries.

The ideas behind the creation of national museums developed slowly out of the practice of representing, ordering and exploring the world by making collections and displaying them. A higher appreciation of the materiality of being and of values as a road to knowledge and prosperity challenged earlier religious and idealistic ideas of the futility of matter. The shockwave of the French Revolution and the Napoleonic contest moved valuables across the continent. Though countries were later liberated from occupation, the need to strengthen the will of the subjects to defend their unity and sovereignty escalated. Subscription of soldier, higher taxation and national loyalty could not be reached only by coercion. Pride, identification and community building with a national dimension needed stronger representation in the imagery. The creation of national museums was one of the prestigious means of processing the urge for knowledge, education and grandeur, not only through representing an existing world, but by their establishment presenting and creating new ideals and communities for the future. Europe has since then seen industrialism, colonialism, two world wars, the Cold War, the fall of the Soviet empire, migrations, globalization and environmental threats, while at the same time growing to tremendous affluence and prosperity. Trying to understand and handle tensions created by history and change is part of the cultural infrastructure of contemporary Europe and the world.

National museums are authoritative spaces for the display and negotiation of community and citizenship, and they have the scientific advantage for comparative exploration of being there over time and in all nation states, although shaped differently in interesting ways. Through collecting and creating repositories of scientific, historic and aesthetic objects, choices are made that protect and narrate ideas of virtues, uniqueness and place in the wider world.

The first negotiation made by any museum is pointing to an object and arguing that it represents a unique or typical value. From this follows the authoritative and sometimes contested decision what type of reality or value the object represents: the natural world, outstanding art, a craft tradition, an historic event or a foreign culture. The struggles of indigenous peoples to make the representation of their cultures travel from a natural history museum to other departments of the museum as a model of the world are part of that negotiation. This shows one of the dimensions where knowledge and politics interact explicitly. A political community in the making is in need of scientific support for its provenance, its coherence and qualities over time. Through the museums, the quality and unity of the culture is composed to an orchestration of "unity in diversity", involving tuning down political controversies and domesticating differences in favour of the aesthetic pleasure of high art or the admiration and presentation of class and regional difference, in open-air museums like Skansen, as part of the stability and beautiful variation 
harboured in the culture of an allegedly stable and even naturalized national community.

The museum answers explicitly or quietly by interplaying voice and silences in dealing with old conflicts. The dissolution of the Swedish empire in 1809 and 1905 was celebrated in the early 21 st century, but the victories of imperial Sweden in 1658 were passed by quietly. The role of the nation vis-à-vis its neighbours, as part of Europe, a Western tradition and the world community is communicated.

What part of the economy is ready to be the next in line, after agriculture, for ending up at a historical museum, and what parts point towards the future? The question is not always answered post facto but established as an argument for where to place hopes and investments for the future. Utilizing national museums in competition between nations and metropolises as investments in the experience economy is a contemporary factor adding to older objectives of securing heritage. Another example of a will to change or adjust to changing political balances concerns the frequent conflicts about the restitution of objects and human remains.

The narrative of these issues treats questions of historical change in many ways. The EU is troubled by disputes in many dimensions about democratic deficit, migration, territorial expansion, integration and weak performances. A free market as well as ideas of universal human rights are in fact localized, embedded and negotiated in institutions like cultural museums, too. A growing attention to cultural policy as a necessary political dimension to pursuing political goals is feeding into the Seventh Framework Programme for research, which asks for policy-relevant knowledge. Our answer to the call is a project on mapping how and with what consequences authoritative institutions such as national museums create long-standing values and identities in need of attention regardless of political preferences.

\section{A EUROPEAN PROJECT}

In order to shape a cultural policy for an expanding European Union, the understanding of one of its most enduring institutions for creating and contesting political identities is necessary. The focus is on understanding the conditions for using the past in negotiations that recreate citizenship as well as the layers of territorial belonging beyond the actual nationstate.

This project is one of the few humanities projects supported by the Seventh Framework Programme, run by the European Commission. It has grown out of collaboration between university partners connecting with a network of young and senior cultural researchers supported by the Marie Curie programme, and will for three years (2010-2013) proceed by a series of investigations beyond the stereotypical ideas of museums as either a result of outstanding heroic individuals, exponents of a materialization of pure Enlightenment ideas or outright ideological nationalistic constructs disciplining citizens into obedience. ${ }^{1}$

The research is pursued through multidisciplinary collaboration between eight leading institutions and a series of sub-projects (in EUspeak: work packages or WPs) studying institutional path dependencies, the handling of conflicts, modes of representation, cultural policy and visitors' experiences in national museums. Understanding the cultural force of national museums will provide citizens, professionals and policy makers with reflexive tools to better communicate and create an understanding of diversity and community in 
developing cultural underpinning for democratic governance.

The first work to start within the project is called "Mapping and framing institutions 1750-2010: national museums interacting with nation-making". This overview of the most important museums established to fulfil the function of a national museum in all European countries (which, surprisingly, has never been done before) will try to achieve several objectives, all of them possible to attain through the comparative method.

The first project gives us the general patterns of what museums were initiated and realized, by whom, with what agenda and with what consequences. In the first step, it is the interaction with political state-making that is analyzed, covering all EU states. One hypothesis is that the actual history of statemaking is of importance for the role played by museums, since empires, old well-established and unthreatened states did not have and still do not have exactly the same needs as nations more recently struggling to form a nation-state. Finland and Norway show different patterns than Sweden and Denmark; Greece, Italy and Germany have partly different priorities than France or the UK. The role of empires in initiating colonial museums at home or abroad is also considered.

In the second project, our research penetrates deeper into explicit narratives of the unity and destiny of the nation as well as the opposite, the treatment of conflict and "heritage wars" that exist in all nations. There is tension between striving towards a hegemonic representation of the cultural and political history of a country and oppositional voices of many kinds coming from other nations and minorities as well as regional aspects, class and gendered tensions that demand representation in these prestigious arenas or a new narrative assigning them a more prominent role. The conflicts over heritage range from a targeted destruction of heritage in war via international battles for the ownership of artefacts to issues of how to represent or integrate minorities.

All narratives are, however, not explicit. In the third project, the implicit message of architecture, city plans and the whole assemblage of national museums will be interpreted in a number of states. Art museums are especially interesting since they claim to stand for universal aesthetical values but at the same time assess narratives in several dimensions on the grandeur of the host carried by the arrangement of collections and exhibitions. Another aspect of the spatial arrangement of national museums is the relationship between representations centralized to the capital and the existence of various "distributed" performances of the national, such as the Swedish SAMDOK. How is the national constructed in collecting and interacting with regional identities and marginalized communities? The third dimension, which is also a new form of distribution, is to interpret the impact of new assemblages of digital museums, like the representation of communities that goes beyond the individual museum.

National museums have from the start been utopian visionary projects carried by politicians, intellectuals, scholars and citizens in the state and in civil society. The hopes of cultural politicians to use museums as tools for education, tourism and integration interplay with the formulation of the national museum professionals and directors themselves. In the fourth project, this dynamic is explored for the last two decades on both national and European policy-making levels. 
Now that we have a good view of the set-up, trajectories and importance of the institutional framework, the explicit and implicit narratives that negotiate meaning, conflicts and directions, and the major actors' hopes for the future, the question remains: How does this matter to the audience? The fifth study concerns audiences in a set of European countries with a view to mapping the experience of visiting by both quantitative and qualitative methods.

In projects financed by the Seventh Framework Programme, a great deal of weight is put on communication. A communication plan is required to develop the identification of stakeholders and the means to communicate with them. Websites, newsletters, policy briefs, reference groups and material for exhibitions are some of the means used. The final project involves extracting the most relevant results and inserting them in a global context by exploring the working of national museums beyond Europe. Conferences are part of the running programme with the final one in Budapest in December 2012 going to focus on broad participation and on identifying the multi-dimensional relevance of the results. The major results will be available via Open Access, but a series of books will also come out of the efforts. The best way to keep up is to follow www.eunamus.eu.

To provide a taste of the comparative scope of the project, I will hint at some reflections coming from the first study of how the institutional frameworks have evolved differently in the Nordic countries. An expanding Nordic research will without doubt feed into this European project. ${ }^{2}$

\section{NORDIC NATIONAL MUSEUMS}

The Nordic context is an exciting arena for comparing several of these dimensions. The call for national museums came early in a Denmark threatened by bombardment and disaster in the early 19th-century Napoleonic wars. Initiatives were, of course, also called for in Sweden, which, after the loss of Finland and the establishment of a new dynasty on the throne, had a need for negotiating its legitimacy as well as meeting the demands of the constitutional monarchy of 1809 . The contract between rulers and ruled everywhere needed new cultural manifestations within the flexible context of the nation. The transformation was more rapid in Denmark, as the royal collections within an absolute monarchy could rather simply, even if somewhat paradoxically, be transformed to a collective national asset by the King. In Sweden, more elaborate and tedious negotiating with the Parliament postponed the inauguration of a national museum in its own building until $1866 .^{3}$

All the Scandinavian countries also held civic and academic collections as part of the Enlightenment movement, which could be used as material and inspiration for new national museums. These became more important by being the exclusive repository in Iceland, Norway and Finland, which, due to their history as peripheral provinces only eventually regaining independence from the old conglomerate states, did not have direct access to the assets in the old capitals. Following on natural history collections in the service of science, art associations took on the task to educate painters and citizens alike and to set up national representations in Finland and Norway as well. In Denmark, the Museum of Danish History, in direct response to Germany's conquest of southern Jutland in 1864 , took on the format it still has as a cabinet of historical paintings of battles and portraits of 
national prominence. National representations in museums developed before sovereign statehood in all the new Nordic states, thus demonstrating the utility of scientific, aesthetical and cultural representation for political purposes.

So far the institutional history is fairly straightforward but there are, however, also several issues brought up by this comparison that are interesting to research in greater depth.

One is to assess the qualities and the impact of the Nordic dimension, especially in 19thcentury museum establishments. In all countries, the presupposition of the existence of a Nordic culture was part both of the naming and the narrative of the museums. Even if this gradually gave way to a stronger nation-state framing, it contributed to an imaginary framing, which geared the policies more towards supporting the neighbouring states rather than resolving conflicts with violence or demanding retribution or vengeance for old injustices. This is in sharp contrast to previous centuries' use of the Nordic ideology.

Another issue is the difference between the Norwegian and the Finnish museum structures. Why is it that Finland has a very clear set of national museums in both art and cultural history that narrate a long comprehensive story of the nation, while Norway does not? You have to visit several museums in Oslo to obtain a comprehensive image, and only at Maihaugen in Lillehammer north of Oslo will the visitor encounter the long story of the national history. Both modern states were born out of a strong need to emphasize their historical existence and unique culture and both lacked royal - and to a large extent aristocratic - sponsors. I suggest that it has to do mainly with the understanding of a national community as primarily born out of rural communities in Norway, which would be paradoxical to represent too strongly in the new capital and former city of Danish rulers. In addition to this, a strong sense of regional differences is voiced from different parts of Norway. In a European comparison, there are other countries showing a similar lack of explicit and coherent national representation in their national museums. Italy, for partly the same reasons (strong local, regional but urban identities), differs greatly from the UK, Sweden or Portugal and other old empires where the alleged universalisms of their political and enlightened endeavours had a stronger foothold. In Denmark, on the other hand, the external threat was so strongly felt that the country's imperial character gave way to the cultural behaviour of a small and threatened state.

Another very interesting difference lies in the choice of narrating the nation, most clearly exemplified by Sweden and Denmark, but also challenging European museums in general. In Sweden, multicultural policy is very strong and is also reflected in the museums. This is most apparent in the Swedish National Historical Museum, which purports to present a history before Sweden and Swedes existed and thus relativizes the nation with its critical view of nationalism. It addresses the visitor as an individual, with men and women, poor and wealthy equally represented, and suggests no evolution or progression as pre-history moves from Stone Age to Iron Age. It offers a large area for reflection on universal issues of death, power and identity. However, since all material comes from present-day Sweden, especially from Skåne (which has only been Swedish for 350 years), the approach becomes deeply anachronistic by reflecting present-day values rather than challenging them. 
The opposite is the case in Denmark. The pre-historical exhibition at the National Museum of Denmark is new and has substituted a surprising format for the preceding one, which was more like the Swedish exhibition, open-ended and with no clear chronological path suggested. The new approach is crystal clear: it starts with the Jelling stone and ends with the Jelling stone. It is a national exhibition and in the clear chronological timeline progression the first skeleton found is a Danish girl. The frame is set and never questioned, even though the borders to the south on the map are somewhat fluid. ${ }^{4}$

There are a great many questions for further research here, as museums and policy makers all over Europe are struggling to find a viable way to combine security and community with tolerance and creativity. They strike the balance differently, but what is the role of museums in this: are they just reflections of their policy makers? Are they actively pushing policy makers in any direction by the power of their representation? Are they representing deeper differences in collective cultural mentalities? How are the exhibitions apprehended by visitors with various backgrounds?

These questions can be raised now, through comparative reflection, and will be possible to answer with more rigour when the results of the research have evolved. Only to break out of the single institution of a single-nation explanatory box is, however, rewarding for a field such as cultural heritage or museums where a lot of thinking has been framed by the self-evident identification with the nation and institution of the narrator.

\section{NOTER}

1. Among the publications are several conference proceedings, also available on-line at $\mathrm{LiU} \mathrm{E}$ press, and a book linking to the new project. Arne Bugge Amundsen \& Andreas Nyblom, (eds.), National museums in a global world [Elektronisk resurs]: NaMu III: Department of culture studies and oriental languages, University of Oslo, Norway, 19-21 November 2007, ed., Linköping electronic conference proceedings (Online), 31 (Linköping: Linköping University Electronic Press, 2008); Peter Aronsson \& Magdalena Hillström, (eds.), NaMu, Making National Museums Program. Setting the frames, 26-28 February, Norrköping, Sweden [Elektronisk resurs], ed., Linköping electronic conference proceedings (Online), 22 (Linköping: Linköping University Electronic Press, 2007); Peter Aronsson \& Andreas Nyblom, (eds.), Comparing: national museums, territories, nation-building and change. NaMu IV, Linköping University, Norrköping, Sweden 18-20 February 2008 : conference proceedings, ed., Linköping electronic conference proceedings (Online), 30 (Linköping: Linköping University Electronic Press, 2008); S.J. Knell, P. Aronsson, and A. et al (eds.) Amundsen, National museums. New studies from around the world, ed. (London: Routledge, 2011). The earlier project was presented in Peter Aronsson, "Making National Museums (NaMu) - ett internationellt program för jämförande studier rörande nationalmuseernas framväxt och funktion," Nordisk Museologi, no. 1 (2007); P. Aronsson et al., "NaMu: EU Museum Project connects and educates scholars from around the world," MUSE 26, no. 6 (2008) and is still available at www.namu.se.

2. See for example the new museum history in Finland, Susanna Pettersson \& Pauliina Kinanen (eds.), Suomen museohistoria, (Helsinki: Suomalaisen Kirjallisuuden Seura, 2010). In Norway 
Anne Eriksen, Museum. En kulturhistorie (Oslo: Pax, 2009) Arne Bugge Amundsen \& Bjarne Rogan, Samling og museum. Kapitler av museenes historie, praksis og ideologi. (Oslo: Novus, 2011). Several relevant projects in Sweden include two at Tema $Q$ at Linköping and several in Stockholm at Historiska Museet, Nordiska Museet and Etnografiska Museet. See:

http://hem.bredband.net/johahega/historisktmuseum/Valkommen.html; http://www.nordicspaces.eu/Nordic/Nordic_Spaces.html. Magdalena Hillström, Ansvaret för kulturarvet. Studier i det kulturhistoriska museiväsendets formering med särskild inriktning på Nordiska museets etablering 1872-1919, ed., Linköping studies in arts and science, 363 (Linköping: Dept. of Culture Studies Linköpings univ., 2006); Eva Insulander, Tinget, rummet, besökaren: om meningsskapande på museum, ed. (Stockholm: Institutionen för didaktik och pedagogiskt arbete, Stockholms universitet, 2010); Fredrik Svanberg, Museer och samlande, ed. (Stockholm: Statens historiska museum, 2009). Contributing to Eunamus on Norden are Peter Aronsson, Henrik Zipsane, Per Widén, Arne Bugge Amundsen, Susanna Pettersson, Eva Silvén, Johan Hegardt, Richard Petersson and Magdalena Hillström. The first set of reports will be presented in Bologna at the end of March 2011.

3. Peter Aronsson, 'Representing community: National museums negotiating differences and community in Nordic countries," Scandinavian Museums and Cultural Diversity, Katherine J. Goodnow \& Haci Akman, (eds.) (New York: Berghahn Books, 2008); Per Widén, Från kungligt galleri till nationell museum. Aktörer, praktik och argument $i$ svensk konstmuseal diskurs $c a$ 1814-1845 (Hedemora: Gidlund, 2009).

4. Peter Aronsson, 'Explaining National Museums. Exploring comparative approaches to the study of national museums," National museums. New studies from around the world, S.J. Knell, P. Aronsson, and A. Amundsen, (eds.) (London: Routledge, 2011).

* Peter Aronsson, professor, Culture Studies (Tema Q), Department for Studies of Social Change and Culture (ISAK), Linköping University, Sweden

Address: Kungsgatan 38, Campus Norrköping, SE-601 74 Norrköping, Sweden

E-mail: peter.aronsson@liu.se

Web: www.isak.liu.seltemaq; www.eunamu.eu; www.aronsson.nl 